\title{
Country food consumption in Yukon, Northwest Territories and Nunavut, Foodbook study 2014-2015
}

\author{
Vanessa Morton ${ }^{1 *}$, Anna Manore ${ }^{1}$, Nadia Ciampa², Shiona Glass-Kaastra², Matt Hurst², \\ Angie Mullen ${ }^{3}$, Jennifer Cutler ${ }^{1}$
}

\section{Abstract}

Background: This article presents a descriptive summary of the consumption of various country food (i.e. locally harvested plant and animal foods) products by residents of Yukon (YT), Northwest Territories (NT) and Nunavut (NU). Data were collected as part of the Foodbook study in 2014-2015.

Methods: The Foodbook study was conducted by telephone over a one-year period. Respondents were asked about consumption of a wide range of food products over the previous seven days. Residents of the territories were also asked about consumption of regionally-specific country food. Data were weighted to develop territorial estimates of consumption. Data on age, gender, location, income and education were also collected.

Results: The national response rate for the Foodbook survey was $19.9 \%$. In total, 1,235 residents of the territories participated in the study ( $Y T, n=402 ; N T, n=458 ; N U, n=375)$. Consumption of any country food during the previous seven days was reported by $77.5 \%$, $60.7 \%$, and $66.4 \%$ of participants in NU, NT and YT, respectively.

Conclusion: Responses to country food questions asked alongside the main Foodbook questionnaire provide insight on country food consumption in YT, NT and NU.
This work is licensed under a Creative Commons Attribution 4.0 International License.

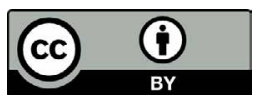

Affiliations

${ }^{1}$ Outbreak Management Division, Public Health Agency of Canada, Guelph, ON

${ }^{2}$ Foodborne Disease and AMR Surveillance Division, Public Health Agency of Canada, Guelph, ON

${ }^{3}$ Department of Health, Government of Nunavut, Iqaluit, NU

\section{*Correspondence: \\ vanessa.morton@canada.ca}

Suggested citation: Morton V, Manore A, Ciampa N, Glass-Kaastra S, Hurst M, Mullen A, Cutler J. Country food consumption in Yukon, Northwest Territories and Nunavut, Foodbook study 2014-2015. Can Commun Dis Rep 2021;47(1):30-6. https://doi.org/10.14745/ccdr.v47i01a06

Keywords: food consumption, country food, Nunavut, Northwest Territories, Yukon

\section{Introduction}

Accurate, comprehensive, and current food consumption data are important for informing public health programming and policy development regarding food security and nutrition, as well as foodborne disease outbreak investigations. In Canada, national food consumption data are available through the Canadian Community Health Survey conducted in 2004 and $2015(1,2)$. Unfortunately, this survey did not collect data on food consumption in Yukon (YT), Northwest Territories (NT) or Nunavut (NU). As a result, there are limited data from national studies that provide insight on food consumption among residents of YT, NT and NU. The Foodbook study was developed to gather comprehensive food consumption data relevant for outbreak investigations in all provinces and territories. The Foodbook study employed a telephone survey to collect food exposure data from residents of all provinces and territories. The Foodbook survey was administered over a one-year period in 2014-2015 using a seven day recall period. Foodbook survey data have since informed the response to outbreaks of foodborne illness in Canada by providing investigators with food exposure reference values which can assist in hypothesis generation (3-6).

In addition to the foods included in the national Foodbook survey, supplementary country foods were included specifically for residents of YT, NT and NU, as recommended by territorial government representatives. Country foods include those that are harvested from the land, water and/or ice, and can include land mammals such as caribou or moose, marine mammals such as seal or walrus, fish and seafood such as Arctic char, clams and mussels, birds such as geese or ptarmigan, and plants such as berries (7-9). Country foods are consumed in YT, NT and NU, as well as in other areas of Canada. While country foods may be 
consumed by individuals of diverse cultural backgrounds, the harvesting, preparation, sharing and consumption of country foods support connections to cultural heritage for Indigenous peoples (10). In addition to supporting connections to cultural heritage, country foods are often perceived as tastier, more nutritious and less expensive than store-bought foods $(7,11,12)$. Country foods can be obtained by hunting or gathering, sharing among community, family or friends, from local hunters' and trappers' organizations, or from businesses that or individuals who sell country food $(7,11-13)$.

As with data from the national Foodbook study, country food consumption data were collected with the aim of quantifying the prevalence of consumption of country foods, information that was not available from previous national surveys. In the event of an outbreak of foodborne illness in YT, NT or NU, these data on country food consumption frequencies may assist investigators in evaluating specific country foods as potential food exposures of interest. These data are also potentially useful for work on nutrition, food security, other health research, as well as policy development.

\section{Methods}

\section{Data collection}

Data on country food consumption were collected as part of the larger national Foodbook study. Foodbook was a population-based telephone survey conducted in all Canadian provinces and territories, from April 2014 to April 2015 with monthly quotas to ensure representativeness over the different seasons. Foodbook interviews were administered in English and French in all provinces and territories, and English, French and Inuktitut in Nunavut. Proxy respondent were used for individual under the age of consent or for individuals with medical or activity limitations. On-demand verbal translation was available for other languages as needed. The study design and sampling methodology for the Foodbook study are described in detail in the published report (14). Briefly, a landline telephone and cell phone sampling frame were used to select respondents from each territory. In addition to demographic questions (e.g. education level, household income, forward sortation area), participants were asked if they consumed various specific food items during the previous seven days. Food consumption questions included items within the categories of fruits, vegetables, herbs and spices, nuts, meats, fish and shellfish, eggs, dairy products and country foods. A copy of the questionnaire is available through Open Data (15). Questions related to country food consumption were asked only of participants in YT, NT and NU. Country food questions were drafted and reviewed with territorial government representatives to ensure that the included country food items were reflective of animal and plant species available and/or consumed in each territory.
The Foodbook study was reviewed and approved by the Health Canada and the Public Health Agency of Canada's Research Ethics Board (REB 2013-0025) and the Newfoundland and Labrador Health Research Ethics Authority (HREB 13.238).

\section{Statistical analysis}

Data were cleaned, coded and analysed using Stata 15.1 for Windows (StataCorp LP, College Station, Texas, United States). Missing values, such as respondents declining to answer a question, were removed from the analysis for those specific questions. Proportions were calculated using survey weights, the details of which are described in the Foodbook Report (14).

Composite variables describing categories of foods were created based on biological categorization and consultation with territorial government representatives. These composite variables included any country foods, large game, small game, wild poultry, marine mammals, fish, wild eggs and plants. Composite variables were coded as "yes" if the individual reported consuming at least one of the items and "no" if the respondent did not report consuming any of the items.

An adjusted Wald's test was used to assess significant differences in the composite variable "any country food" between categories of demographic variables (i.e. age, education, income and location). The categories reporting the highest proportion of country food consumption served as referent groups. Comparisons with $p<0.05$ were considered statistically significant.

\section{Results}

A total of 1,235 individuals from YT $(n=402), N T(n=458)$ and NU $(n=375)$ participated in the Foodbook study. The geographic distribution of survey respondents was reflective of the geographic distribution of residents within the territories. Since location was based on the first three digits of participants' postal codes, it was not possible to separate the data from lqaluit from the remainder of the Qikiqtani Region in Nunavut. Ninety-nine percent of participants in YT and NT completed the survey in English, and the remaining 1\% completed the survey in French. Ninety-three percent of participants in NU completed the survey in English, 6\% completed the survey in Inuktitut and 1\% completed the survey in French.

The age and gender distribution of Foodbook participants in each territory were adjusted using survey weights to be similar to the age and gender distribution of the populations of their respective territories (Table 1 ).

A larger proportion of Foodbook participants in YT, NT and NU reported a "Bachelor's degree or a degree above the Bachelor's level" than the census populations of their respective territories (Table 1). In addition, a smaller proportion of Foodbook participants, than census populations, in the territories reported 
Table 1: Demographics, education and income characteristics of weighted Foodbook respondents compared to census data, Yukon, Northwest Territories and Nunavut, 2014-2015

\begin{tabular}{|c|c|c|c|c|c|c|}
\hline \multirow[b]{2}{*}{$\begin{array}{c}\text { Demographics, education and income } \\
\text { characteristics }\end{array}$} & \multicolumn{2}{|c|}{ Yukon } & \multicolumn{2}{|c|}{ Northwest Territories } & \multicolumn{2}{|c|}{ Nunavut } \\
\hline & $\begin{array}{l}\text { Foodbook } \\
\text { (\%) }\end{array}$ & $\begin{array}{c}\text { Census } \\
\text { population } \\
(\%)\end{array}$ & $\begin{array}{l}\text { Foodbook } \\
\text { (\%) }\end{array}$ & $\begin{array}{c}\text { Census } \\
\text { population } \\
(\%)\end{array}$ & $\begin{array}{l}\text { Foodbook } \\
(\%)\end{array}$ & $\begin{array}{c}\text { Census } \\
\text { population } \\
(\%)\end{array}$ \\
\hline \multicolumn{7}{|l|}{ Gender $^{\mathrm{a}}$} \\
\hline Male & 50.3 & 50.9 & 50.8 & 51.1 & 51.4 & 51.5 \\
\hline Female & 49.7 & 49.1 & 49.2 & 48.9 & 48.6 & 48.5 \\
\hline \multicolumn{7}{|l|}{ Age group ${ }^{a}$} \\
\hline $0-9$ years & 11.5 & 11.3 & 14.8 & 14.1 & 22.9 & 22.8 \\
\hline 10-19 years & 12.4 & 10.9 & 15.1 & 13.2 & 19.3 & 18.0 \\
\hline 20-64 years & 67.1 & 67.6 & 64.3 & 66.2 & 54.4 & 55.7 \\
\hline $65+$ years & 9.1 & 10.2 & 5.8 & 6.5 & 3.3 & 3.5 \\
\hline \multicolumn{7}{|l|}{ Education ${ }^{b, c}$} \\
\hline Less than high school diploma & 9.5 & 10 & 28.4 & 18 & 45.6 & 49 \\
\hline High school diploma & 17.4 & 21 & 14.3 & 22 & 5.4 & 15 \\
\hline $\begin{array}{l}\text { Trade, college or non-university certificate/diploma } \\
\text { below the Bachelors' level }\end{array}$ & 41.1 & 39 & 28.7 & 37 & 17.2 & 23 \\
\hline $\begin{array}{l}\text { Bachelor's degree and certificates/degrees above the } \\
\text { Bachelors' level }\end{array}$ & 31.2 & 29 & 27.0 & 23.0 & 29.7 & 13.0 \\
\hline Not reported & 0.8 & NA & 1.5 & NA & 2.2 & NA \\
\hline \multicolumn{7}{|l|}{ Household income $^{d}$} \\
\hline Less than $\$ 30,000$ & 10.8 & 17.3 & 10.4 & 15.3 & 21.8 & 28.0 \\
\hline$\$ 30,000-\$ 60,000$ & 18.3 & 17.2 & 7.2 & 15.1 & 3.9 & 22.4 \\
\hline$\$ 60,000-\$ 80,000$ & 14.1 & 14.1 & 13.1 & 9.1 & 10.5 & 8.6 \\
\hline More than $\$ 80,000$ & 49.0 & 51.5 & 52.2 & 60.5 & 42.9 & 41.0 \\
\hline Not reported & 7.8 & NA & 17.1 & NA & 21.0 & NA \\
\hline \multicolumn{7}{|l|}{ Location $^{\mathrm{e}}$} \\
\hline Territorial capital & 80.3 & 77.1 & 45.6 & 48.0 & 61.9 & 52.3 \\
\hline Outside capital region & 19.2 & 22.8 & 50.2 & 52.0 & 38.1 & 47.3 \\
\hline Not reported & 0.5 & NA & 0.2 & NA & NA & NA \\
\hline
\end{tabular}

Abbreviation: NA, not applicable

a Territorial population data from Statistics Canada. Table 17-10-0005-01 Population estimates on July 1st, by age and sex (2014 data)

b Territorial population data Statistics Canada. Table 37-10-0117-01 Educational attainment in the population aged 25 to 64 years, off-reserve Aboriginal, non-Aboriginal and total population

c Question only asked of Foodbook respondents older than 25 years of age

derritorial data from Statistics Canada, Canadian Community Health Survey, 2013-2014

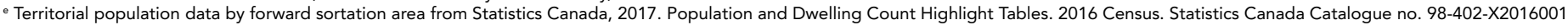

Ottawa. Released February 8, 2017

annual household incomes under $\$ 60,000$. Survey weights were not used to adjust the distribution of education or annual household income among Foodbook participants.

Consumption of one or more country foods during the previous seven days was reported by $66.4 \%$ Foodbook participants in YT, $60.7 \%$ in NT and $77.5 \%$ in NU (Table 2). Foodbook respondents aged 0-9 years in YT and NT were less likely to report eating any country food in the previous seven days compared with those aged 20-64 years. No other statistically significant differences were noted between age categories (Table 2). The proportion of Foodbook respondents reporting any country food consumption with a household income of less than $\$ 30,000$ was significantly higher than the proportion among respondents with a household income of greater than $\$ 80,000$ in all three territories.

There were no significant differences in the composite variable "any country food" reported among categories of the education variable in YT and NT. In contrast, in NU, the prevalence of country food consumption was significantly higher among respondents with "less than high school diploma" and those with a "trade, college or non-university certificate/diploma" when compared with respondents with a "Bachelor's degree or a degree above the Bachelor's level". The proportion of 
Table 2: Characteristics of Foodbook respondents reporting consuming any country food in the previous seven days, Yukon, Northwest Territories and Nunavut, 2014-2015

\begin{tabular}{|c|c|c|c|c|c|c|c|c|c|}
\hline \multirow{2}{*}{ Characteristics of respondents } & \multicolumn{3}{|c|}{ Yukon } & \multicolumn{3}{|c|}{ Northwest Territories } & \multicolumn{3}{|c|}{ Nunavut } \\
\hline & $\%$ & $95 \% \mathrm{Cl}$ & $p$ & $\%$ & $95 \% \mathrm{Cl}$ & $p$ & $\%$ & $95 \% \mathrm{Cl}$ & $p$ \\
\hline Any country food consumption & 66.4 & $57.6-74.2$ & NA & 60.7 & $52.2-68.5$ & NA & 77.5 & $70.2-83.5$ & NA \\
\hline \multicolumn{10}{|l|}{ Gender } \\
\hline Male & 64.58 & $51.3-75.9$ & 0.6636 & 57.0 & $43.5-69.6$ & 0.3704 & 73.7 & $63.3-82.0$ & 0.2460 \\
\hline Female $^{a}$ & 68.2 & $56.6-78.0$ & NA & 64.5 & $54.5-73.3$ & NA & 81.6 & 70.4-89.1 & NA \\
\hline \multicolumn{10}{|l|}{ Age group } \\
\hline $0-9$ years & $53.3^{b}$ & $41.6-64.7$ & 0.0452 & $47.0^{\mathrm{b}}$ & $36.3-58.0$ & 0.0445 & 69.3 & $36.3-58.0$ & 0.3644 \\
\hline $10-19$ years & 61.0 & $46.8-73.6$ & 0.3112 & 56.8 & $44.3-68.5$ & 0.4291 & 88.5 & $44.3-68.5$ & 0.1119 \\
\hline $20-64$ years $^{a}$ & 70.3 & $57.5-80.5$ & NA & 63.7 & $51.1-74.7$ & NA & 76.4 & $51.1-74.7$ & NA \\
\hline $65+$ years & 61.6 & $50.0-71.9$ & 0.2877 & 71.4 & $57.7-82.1$ & $0.378^{c}$ & 88.6 & $57.7-82.1$ & 0.1619 \\
\hline \multicolumn{10}{|l|}{ Education } \\
\hline Less than high school diploma & 86.9 & $68.1-95.3$ & 0.0709 & 73.1 & $38.5-92.2$ & 0.5064 & $94.5^{\mathrm{b}}$ & 73.7-99.0 & 0.0007 \\
\hline High school diploma & 65.1 & $39.0-84.5$ & 0.9847 & 60.6 & $37.6-79.7$ & 0.9467 & 57.4 & $20.8-87.4$ & 0.9469 \\
\hline $\begin{array}{l}\text { Trade, college or non-university } \\
\text { certificate/diploma below the } \\
\text { Bachelor's level }\end{array}$ & 72.8 & $52.1-86.8$ & 0.5599 & 58.8 & $41.0-74.5$ & 0.8246 & $83.7^{b}$ & $62.7-94.0$ & 0.0303 \\
\hline $\begin{array}{l}\text { Bachelor's degree and certificates/ } \\
\text { degrees above the Bachelor's level }\end{array}$ & 64.8 & $43.1-81.7$ & NA & 61.6 & $42.8-77.5$ & NA & 55.9 & $36.0-74.0$ & NA \\
\hline \multicolumn{10}{|l|}{ Income } \\
\hline Less than $\$ 30000$ & $84.9^{c}$ & 67.0-93.9 & 0.0088 & $76.9^{b}$ & $56.1-89.7$ & 0.0124 & $89.7^{b}$ & $73.3-96.5$ & 0.0137 \\
\hline$\$ 30,000-\$ 60,000$ & 69.5 & 50.5-83.6 & 0.3981 & 53.6 & $35.2-71.1$ & 0.8884 & 68.4 & $39.6-87.8$ & 0.8512 \\
\hline$\$ 60,000-\$ 80,000$ & 67.5 & $48.3-82.2$ & 0.5159 & 51.3 & $24.8-77.1$ & 0.9609 & 67.1 & $38.6-86.9$ & 0.7802 \\
\hline More than $\$ 80,000^{a}$ & 60.3 & $47.0-72.2$ & NA & 52.1 & $42.7-61.4$ & NA & 71.1 & $59.8-80.2$ & NA \\
\hline \multicolumn{10}{|l|}{ Location } \\
\hline Territorial capital ${ }^{\mathrm{b}}$ & $62.0^{\mathrm{b}}$ & $51.6-71.4$ & 0.0018 & $47.8^{b}$ & $37.8-58.0$ & 0.0039 & 73.1 & 63.1-81.3 & 0.1031 \\
\hline Outside capital region ${ }^{a}$ & 84.2 & $72.1-91.6$ & NA & 71.0 & $57.9-81.3$ & NA & 83.8 & $72.8-90.9$ & NA \\
\hline
\end{tabular}

respondents consuming any country food was significantly higher in areas of YT and NT that are outside of the capital regions of Whitehorse and Yellowknife (Table 2).

The specific country foods consumed in the previous seven days varied by territory (Table 3 ). In YT, the most commonly reported country food was moose $(46.0 ; 95 \% \mathrm{Cl} 35.9-56.1)$, followed by berries from the land (28.3; 95\% Cl 18.3-38.4). In NT, whitefish was the most commonly reported country food consumed (25.8; 95\% Cl 16.7-34.8) followed by caribou (22.0; 95\% Cl 13.0-31.1) and moose (19.8; 95\% Cl 13.0-31.1). In Nunavut, caribou (57.2; 95\% Cl 48.6-65.9) and Arctic char (52.3; 95\% Cl 43.4-61.2) were the two most commonly reported country foods. Sea mammals (e.g. seal, walrus, beluga, narwhal and bowhead) were consumed by $43.2 \%$ ( $95 \% \mathrm{Cl} 34.1-52.3)$ of Nunavut participants. Consumption of non-country by residents of YT, NT and NU are reported in the Foodbook report (14).
Table 3: Weighted Foodbook respondents reporting consumption of country food items in the previous seven days, Yukon, Northwest Territories and Nunavut, 2014-2015

\begin{tabular}{|l|r|r|r|r|r|r|}
\multirow{2}{*}{$\begin{array}{c}\text { Country } \\
\text { food items }\end{array}$} & \multicolumn{2}{|c|}{ Yukon } & \multicolumn{2}{c|}{$\begin{array}{c}\text { Northwest } \\
\text { Territories }\end{array}$} & \multicolumn{2}{c|}{ Nunavut } \\
\cline { 2 - 7 } & $\%$ & $95 \% \mathrm{Cl}$ & \multicolumn{1}{c|}{$\%$} & $\mathbf{9 5 \%} \mathrm{Cl}$ & \multicolumn{1}{c|}{$\%$} & $95 \% \mathrm{Cl}$ \\
\hline $\begin{array}{l}\text { Any country } \\
\text { food }\end{array}$ & 66.4 & $58.1-74.7$ & 60.7 & $\begin{array}{r}52.4- \\
68.9\end{array}$ & 77.5 & $\begin{array}{r}70.9- \\
84.2\end{array}$ \\
\hline Large game & 51.9 & $42.2-61.6$ & 41.5 & $\begin{array}{r}32.2- \\
50.8\end{array}$ & 59.4 & $\begin{array}{r}50.8- \\
67.9\end{array}$ \\
\hline Caribou & 12.6 & $6.5-18.7$ & 22.0 & $\begin{array}{r}13.0- \\
31.1\end{array}$ & 57.2 & $\begin{array}{r}48.6- \\
65.9\end{array}$ \\
\hline Muskox & $\mathrm{NA}$ & $\mathrm{NA}$ & 3.4 & $\begin{array}{r}0.6-6.2 \\
9.8\end{array}$ & $\begin{array}{r}3.8- \\
15.8\end{array}$ \\
\hline Polar bear & $\mathrm{NA}$ & $\mathrm{NA}$ & 0.0 & $0-0.01$ & 5.6 & $2.5-8.7$ \\
\hline Moose & 46.0 & $35.9-56.1$ & 19.8 & $\begin{array}{r}13.0- \\
26.7\end{array}$ & NA & NA \\
\hline Bear & 0.5 & $0-1.2$ & 0.9 & $0-2.5$ & NA & NA \\
\hline
\end{tabular}


Table 3: Weighted Foodbook respondents reporting consumption of country food items in the previous seven days, Yukon, Northwest Territories and Nunavut, 2014-2015 (continued)

\begin{tabular}{|c|c|c|c|c|c|c|}
\hline \multirow{2}{*}{$\begin{array}{l}\text { Country } \\
\text { food items }\end{array}$} & \multicolumn{2}{|c|}{ Yukon } & \multicolumn{2}{|c|}{$\begin{array}{l}\text { Northwest } \\
\text { Territories }\end{array}$} & \multicolumn{2}{|c|}{ Nunavut } \\
\hline & $\%$ & $95 \% \mathrm{Cl}$ & $\%$ & $95 \% \mathrm{Cl}$ & $\%$ & $95 \% \mathrm{Cl}$ \\
\hline Bison & 12.1 & $6.0-18.3$ & 10.3 & $5.0-15.5$ & NA & NA \\
\hline Elk/deer & 4.5 & $0-11.2$ & 2.5 & $0.1-4.9$ & NA & NA \\
\hline Sheep & 3.9 & $0-8.5$ & 1.3 & $0-3.0$ & NA & NA \\
\hline Wild poultry & 4.3 & $0.2-8.5$ & 6.6 & $3.2-10.1$ & 8.6 & $5.2-12.0$ \\
\hline Geese & NA & NA & 2.9 & $1.0-4.8$ & 6.6 & $3.6-9.7$ \\
\hline Duck & NA & NA & 2.7 & $0.8-4.7$ & 1.7 & $0.3-3.0$ \\
\hline $\begin{array}{l}\text { Ptarmigan/ } \\
\text { grouse }\end{array}$ & 4.3 & $0.2-8.5$ & 3.7 & $0.8-6.6$ & 3.2 & $1.1-5.4$ \\
\hline Sea mammals & NA & NA & 3.0 & $0.3-5.6$ & 43.2 & $34.1-52.3$ \\
\hline Seal & NA & NA & 0.8 & $0-2.3$ & 28.9 & $20.3-37.5$ \\
\hline Walrus & NA & NA & 0.0 & $0-0.01$ & 5.2 & $2.0-8.4$ \\
\hline Beluga & NA & NA & 2.2 & $0-4.4$ & 21.8 & $14.1-29.4$ \\
\hline Narwhal & NA & NA & 0 & $0-0.01$ & 11.6 & 6.8-16.4 \\
\hline Bowhead & NA & NA & 0 & $0-0.01$ & 0.6 & $0-1.3$ \\
\hline $\begin{array}{l}\text { Small land } \\
\text { mammals }\end{array}$ & 2.9 & $0-6.7$ & 5.3 & $1.9-8.6$ & NA & NA \\
\hline Gophers & 2.4 & $0-6.2$ & 0.0 & $0-0.01$ & NA & NA \\
\hline $\begin{array}{l}\text { Beaver/ } \\
\text { muskrat }\end{array}$ & 0.0 & $0-0.01$ & 0.8 & $0-1.7$ & NA & NA \\
\hline Rabbit & 2.9 & $0-6.7$ & 5.1 & $1.7-8.4$ & NA & NA \\
\hline Any fish & 16.8 & $8.5-25.0$ & 33.7 & $\begin{array}{r}24.7- \\
42.7\end{array}$ & 53.9 & $45.0-62.8$ \\
\hline Arctic char & 1.9 & $0.5-3.3$ & 6.9 & $3.2-10.7$ & 52.3 & $43.4-61.2$ \\
\hline Whitefish & 10.0 & $1.8-18.1$ & 25.8 & $\begin{array}{r}16.7- \\
34.8\end{array}$ & 10.8 & $3.6-18.0$ \\
\hline Trout & 9.5 & $2.9-16.2$ & 7.9 & $4.3-11.5$ & 8.2 & $3.6-12.7$ \\
\hline Herring & NA & NA & 0.5 & $0-1.0$ & 0.4 & $0-1.0$ \\
\hline Inconnu & NA & NA & 0.9 & $0-1.9$ & 0.2 & $0-0.3$ \\
\hline Salmon & NA & NA & 12.0 & $8.1-15.9$ & NA & NA \\
\hline Cod & NA & NA & 1.8 & $0.7-2.8$ & 5.9 & $2.6-9.2$ \\
\hline Pike & 6.9 & 0-15.0 & 4.5 & $1.5-7.4$ & NA & NA \\
\hline Wild eggs & NA & NA & 2.5 & $0-5.1$ & 4.9 & $1.5-8.2$ \\
\hline Duck eggs & NA & NA & 1.1 & $0-2.6$ & 3.9 & $0.8-7.0$ \\
\hline Geese eggs & NA & NA & 0 & $0-0.01$ & 2.4 & $0.3-4.6$ \\
\hline $\begin{array}{l}\text { Other wild } \\
\text { eggs }\end{array}$ & NA & NA & 1.7 & $0-3.9$ & 1.3 & $0-2.6$ \\
\hline $\begin{array}{l}\text { Berries from } \\
\text { the land }\end{array}$ & 28.3 & $18.3-38.4$ & 14.4 & $8.5-20.3$ & 13.6 & $8.1-19.1$ \\
\hline Other plants & 6.8 & $2.0-11.7$ & 6.2 & $2.7-9.7$ & 5.8 & $2.4-9.1$ \\
\hline Seaweed & NA & NA & 6.8 & $2.2-11.4$ & 5.9 & $2.3-9.5$ \\
\hline
\end{tabular}

Abbreviation: NA, not applicable

\section{Discussion}

The Foodbook study captured data on food consumption, including country food, among residents of YT, NT and NU. This information fills a gap in national food consumption data. In total, over $60 \%$ of Foodbook respondents in each territory reported consuming one or more country foods in the previous seven days. These data show that country foods comprise a part of the diet for the majority of YT, NT and NU residents. The data reported here, and other data collected through the Foodbook surveys, may be used to fill gaps in knowledge for those pursuing research in the areas of food safety, food security, climate change or nutrition.

Given the diversity of climate, landscape, populations and cultural practices across the three territories, it is difficult to make meaningful comparisons between the territories regarding the types of country food reported. However, some general trends were observed regarding which residents were reporting consuming county foods. In all three territories, the percentage of Foodbook survey respondents consuming country foods increased with age, with the exception of individuals between 20 and 64 years of age in Nunavut. This association between country food and age aligns with the finding of surveys of indigenous populations $(16,17)$. There also appeared to be a link between income and country food consumption. The reasons for this link are unclear but the cost of store-bought foods in some remote communities is quite high so participants with lower annual incomes may be supplementing expensive store-bought food with inexpensive country food. Conversely, other studies have noted that costs associated with hunting can be a barrier to consumption of country foods (7).

Several studies have investigated the frequency and amount of country food consumption in specific region and communities in YT, NT and NU (Table 4). While there are some commonalities between the methods employed in these studies and in the Foodbook study, key differences include the recall periods and method of survey administration. These previous studies also differ from the Foodbook study by target population. The studies included in Table 4 focused on specific Indigenous communities. In contrast, the Foodbook study collected data for the whole territorial population, regardless of ethnicity. These methodological differences make it challenging to compare results between studies. Rather, these studies, taken together, may be seen as complementary, and increase understanding of country food consumption among residents of YT, NT and NU.

The main limitations of the Foodbook study are listed in the Foodbook report (14). One of the specific limitations in the territories was that the survey was administered solely by telephone. This likely affected the representativeness of the study respondents: while $99 \%$ of Canadian households have telephone access, in the territories the number of households with telephone access is likely to be lower than 
Table 4: Select food consumption surveys conducted in Yukon, Northwest Territories and Nunavut

\begin{tabular}{|c|c|c|c|c|}
\hline $\begin{array}{c}\text { Food } \\
\text { consumption } \\
\text { surveys }\end{array}$ & $\begin{array}{c}\text { Inuit } \\
\text { Health } \\
\text { study } \\
(11,18,19)\end{array}$ & $\begin{array}{l}\text { Inuit Child } \\
\text { Health } \\
\text { study (20) }\end{array}$ & $\begin{array}{c}\text { Sharma } \\
\text { Nunavut } \\
\text { study (21) }\end{array}$ & $\begin{array}{l}\text { Foodbook } \\
\text { study }\end{array}$ \\
\hline $\begin{array}{l}\text { Data collection } \\
\text { period }\end{array}$ & $\begin{array}{l}\text { Summer } \\
2007, \\
\text { summer } \\
2008\end{array}$ & $\begin{array}{l}\text { Summer } \\
2007, \\
\text { summer } \\
2008\end{array}$ & $\begin{array}{l}\text { September- } \\
\text { December } \\
2006\end{array}$ & $\begin{array}{l}\text { One-year } \\
\text { period in } \\
2014-2015\end{array}$ \\
\hline $\begin{array}{l}\text { Number of } \\
\text { participants }\end{array}$ & 1,569 & 338 & 188 & 1,235 \\
\hline $\begin{array}{l}\text { Participant } \\
\text { criteria }\end{array}$ & $\begin{array}{l}\text { Inuit adults } \\
\text { living in } \\
\text { communities } \\
\text { in Inuit } \\
\text { settlement } \\
\text { region }\end{array}$ & $\begin{array}{l}\text { Inuit children } \\
3-5 \text { years } \\
\text { old from } 16 \\
\text { communities } \\
\text { in Nunavut }\end{array}$ & $\begin{array}{l}\text { Inuit over } \\
19 \text { years of } \\
\text { age, not } \\
\text { pregnant } \\
\text { in four } \\
\text { communities } \\
\text { in NT and } \\
\text { NU }\end{array}$ & $\begin{array}{l}\text { Residents } \\
\text { of YT, NT } \\
\text { and NU; } \\
\text { selected to } \\
\text { meet quotas } \\
\text { based on } \\
\text { age groups }\end{array}$ \\
\hline Survey method & In-person & In-person & In-person & Telephone \\
\hline Recall period & $\begin{array}{l}12 \text { months } \\
\text { and } 24 \text { hours }\end{array}$ & One month & 24 hours & Seven days \\
\hline
\end{tabular}

southern Canada (22). Another key limitation was the lack of ethnicity data. These data would have provided information on the number of Indigenous people included in the survey and would help to understand links between ethnicity and food consumption habits.

\section{Conclusion}

Overall, the 2014-2015 Foodbook study provided a comprehensive picture of food consumption in Canada and included the territories, which had not been included in previous national studies. It is also important to note that Foodbook study is one of the few national surveys to provide the option to be completed in Inuktitut, which may have resulted in the survey reaching a segment of the population that would not be represented otherwise. Data presented here can provide information to support nutrition, food security, outbreak investigations and other research projects. The addition of country foods to other food consumption studies should be considered in other geographical areas, especially rural and remote areas, to understand the role of country foods in the diet of Canadians.

\section{Authors' statement}

V Morton and J Cutler conceived the idea for this manuscript. $\checkmark$ Morton and A Manore developed the first draft. All authors contributed to the development and revision of this manuscript and approved the final draft for submission.

A Mullen is currently associated with Nova Scotia Department of Health and Wellness.

\section{Competing interests}

None.

\section{Acknowledgements}

The authors acknowledge the Centre for Foodborne, Environmental and Zoonotic Infectious Diseases (Public Health Agency of Canada), Outbreak Management Division and FoodBorne Disease and Antimicrobial Resistance Surveillance Division, provincial and territorial epidemiologists for their assistance with the Foodbook project; the staff at R.A. Malatest \& Associates Ltd. for their expert interviewing. We also thank $J$ Allen from Nunavut Tunngavik Incorporated for reviewing the manuscript.

\section{Funding}

This work is supported by the Public Health Agency of Canada.

\section{References}

1. Public Health Agency of Canada. National single day food consumption report: analysis of the 24-hour dietary recall data from the Canadian Community Health Survey (CCHS), Cycle 2.2, Nutrition (2004), and assessment for food consumption frequency among Canadians. Ottawa (ON): PHAC; 2012. http://publications.gc.ca/site/fra/419161/ publicaton.html

2. Health Canada. Reference Guide to Understanding and Using the Data: 2015 Canadian Community Health Survey - Nutrition. Ottawa (ON): HC; 2017. https://www. canada.ca/en/health-canada/services/food-nutrition/ food-nutrition-surveillance/health-nutrition-surveys/ canadian-community-health-survey-cchs/reference-guid e-understanding-using-data-2015.html

3. Harvey RR, Heiman Marshall KE, Burnworth $L$, Hamel M, Tataryn J, Cutler J, Meghnath K, Wellman A, Irvin K, Isaac L, Chau K, Locas A, Kohl J, Huth PA, Nicholas D, Traphagen E, Soto K, Mank L, Holmes-Talbot K, Needham M, Barnes A, Adcock B, Honish L, Chui L, Taylor M, Gaulin C, Bekal S, Warshawsky B, Hobbs L, Tschetter LR, Surin A, Lance S, Wise ME, Williams I, Gieraltowski L. International outbreak of multiple Salmonella serotype infections linked to sprouted chia seed powder - USA and Canada, 2013-2014. Epidemiol Infect 2017;145(8):1535-44. DOI PubMed

4. Whitfield $Y$, Johnson K, Hanson H, Huneault D. 2015 Outbreak of Cyclosporiasis Linked to the Consumption of Imported Sugar Snap Peas in Ontario, Canada. J Food Prot 2017;80(10):1666-9. DOI PubMed

5. Hobbs JL, Warshawsky B, Maki A, Zittermann S, Murphy A, Majury A, Middleton D. Nuggets of Wisdom: Salmonella Enteritidis Outbreaks and the Case for New Rules on Uncooked Frozen Processed Chicken. J Food Prot 2017;80(4):703-9. DOI PubMed

6. Meghnath K, Hasselback P, McCormick R, Prystajecky N, Taylor M, Mclntyre L, Man S, Whitfield Y, Warshawsky B, McKinley M, Bitzikos O, Hexemer A, Galanis E; Outbreak Team. Outbreaks of Norovirus and Acute Gastroenteritis Associated with British Columbia Oysters, 2016-2017. Food Environ Virol 2019;11(2):138-48. DOl PubMed 
7. Chan HM, Fediuk K, Hamilton S, Rostas L, Caughey A, Kuhnlein H, Egeland G, Loring E. Food security in Nunavut, Canada: barriers and recommendations. Int J Circumpolar Health 2006;65(5):416-31. DOI PubMed

8. Government of Nunavut Department of Health. Nunavut Food Guide. https://livehealthy.gov.nu.ca/sites/default/files/ resource_attachments/EN_WEB_nunavut-food-guide.pdf

9. Nunavut Wildlife Management Board. Priest $H$, Usher PJ. The Nunavut Wildlife Harvest Study. NWMB; 2004. https:// www.nwmb.com/inu/publications/harvest-study/1824156-nwhs-report-2004-156-0003/file

10. Lambden J, Receveur O, Marshall J, Kuhnlein HV. Traditional and market food access in Arctic Canada is affected by economic factors. Int J Circumpolar Health 2006;65(4):33140. DOI PubMed

11. Nunavut Steering Committee. Egeland GM. 2007-2008 Inuit Health Survey: Nunavut. Montreal (QC): McGill; 2010. https://www.mcgill.ca/cine/files/cine/adult_report_nunavut. pdf

12. Inuvialuit Settlement Region Steering Committee. Egeland GM. 2007-2008 Inuit Health Survey: Inuvialuit Settlement Region. Montreal (QC): McGill; 2010. https://www.mcgill.ca/ cine/files/cine/adult_report_-_inuvialuit.pdf

13. Kuhnlein HV, Receveur O. Local cultural animal food contributes high levels of nutrients for Arctic Canadian Indigenous adults and children. J Nutr 2007;137(4):1110-4. DOI PubMed

14. Public Health Agency of Canada. Foodbook Report. Ottawa (ON): PHAC; 2015. https://www.canada.ca/content/ dam/canada/health-canada/migration/healthy-canadians/ publications/eating-nutrition/foodbook-2015/alt/pub-eng. pdf

15. Open Access. https://open.canada.ca/en/open-data
16. Kuhnlein HV, Receveur O, Soueida R, Egeland GM. Arctic indigenous peoples experience the nutrition transition with changing dietary patterns and obesity. J Nutr 2004;134(6):1447-53. DOI PubMed

17. Canadian Radio-television and Telecommunications Commission. Communications Monitoring Report 2018. Ottawa (ON): CRTC; 2019. https://crtc.gc.ca/pubs/cmr2018en.pdf

18. Saudny H, Leggee D, Egeland G. Design and methods of the Adult Inuit Health Survey 2007-2008. Int J Circumpolar Health 2012;71:19752. DOI PubMed

19. Kenny TA, Hu XF, Kuhnlein HV, Wesche SD, Chan HM. Dietary sources of energy and nutrients in the contemporary diet of Inuit adults: results from the 2007-08 Inuit Health Survey. Public Health Nutr 2018;21(7):1319-31. DOI PubMed

20. Egeland GM; Qanuippitali Steering Committee Members. Qanuippitali? The International Polar Year Nunavut Inuit Child Health Survey 2007-2008. IPY; 2009. http://www. inuithealthsurvey.ca/pdf/Child_Inuit_Health_Survey_Aug_31. pdf

21. Sharma S, Cao X, Roache C, Buchan A, Reid R, Gittelsohn J. Assessing dietary intake in a population undergoing a rapid transition in diet and lifestyle: the Arctic Inuit in Nunavut, Canada. Br J Nutr 2010;103(5):749-59. DOI PubMed

22. Receveur O, Boulay M, Kuhnlein HV. Decreasing traditional food use affects diet quality for adult Dene/Métis in 16 communities of the Canadian Northwest Territories. J Nutr 1997;127(11):2179-86. DOI PubMed 